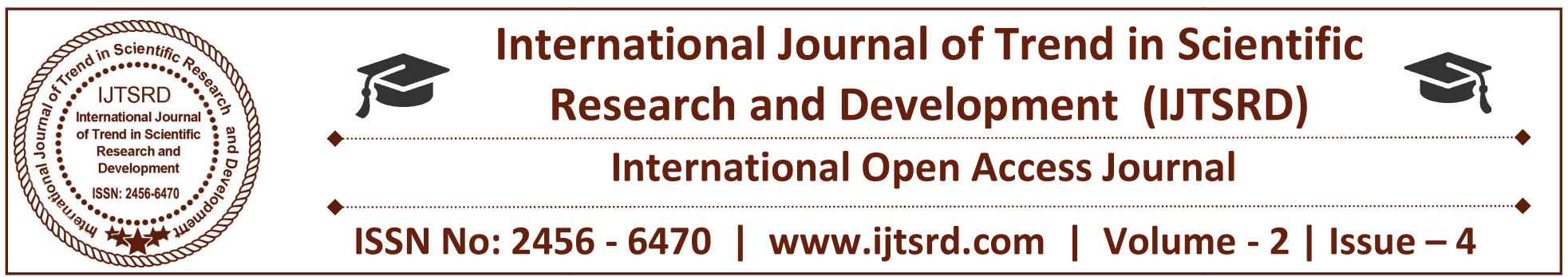

\title{
Female Mathematics Role Models and Girls Performance in Mathematics in the South West Region of Cameroon: A Gender Issue
}

\author{
Bisong Clara Bate AshuMbuoben (Ph.D) \\ Consultant/Lecturer, Department of Development Studies \\ Pan African Institute for Development West Africa (PAID-WA) Buea, Cameroon
}

\begin{abstract}
In Cameroon just like other countries in the world, Mathematics is an important subject with its skills very much needed in applying science and technology for development. There is growing demand for professionals in Science, Technology, Mathematics and Engineering (STEM) to meet up with significant labor shortage in the market. Women are often underrepresented in STEM and it has been noticed generally that females mathematics role models are lacking in the society. The low presence of female mathematicians/Teachers professionals and others who stand for role models are lacking in the schools and society as a whole. This tendency seem to have combined with other environmental and other

shows that when girls are exposed to a female mathematics role models including the female mathematics teachers in schools, there is a positive impact that shows up in their motivation to study mathematics. To improve on the participation and performance of girls, the Researcher recommends that while school administration and other stakeholders in education work hard on making the pedagogy for secondary school mathematics gender sensitive, there should be heavy emphasis to expose students in secondary schools to female mathematics role models who will motivate their participation in mathematics and consequently improve their performance in the subject.
\end{abstract} socioeconomic factors to give the girls a negative attitudes towards mathematics, visible in their lack of interest and low participation in its lessons. This attitude affects their ability to engage with Mathrelated content, leads to poor performance and consequently fewer females pursuing degrees in fields that require a strong mathematics background. This paper seeks to determine how lack of female role models in mathematics negatively affect female student's participation and general performance in mathematics and also to show how female mathematics role models in the schools and society as a whole can be used to improve on the participation and performance of girls in mathematics. Research questions were constructed; feminist theories and other theories in education were employed to guide the study. The study is descriptive and utilized 450 form four students and 44mathematics teachers from 158 public secondary schools in the South West Region of Cameroon. Statistical Package for social science (SPSS) version 12 was used to analyze data collected by research instruments. The findings

Keywords: Role Model, gender, mathematics, Performance

\section{INTRODUCTION}

Skills in mathematics are needed as a vital tool for understanding and applying science and technology for development but in most of our secondary schools in the South West Region of Cameroon, there is the stereotyping of mathematics as a male domain and the frustration in female students caused by some difficulties they face in learning mathematics for which the absence or lack of female mathematics role models is a contributory factor(Nekang FN ,2007) The low presence and sometimes total absence of female role models in mathematics sometimes work together with the other factors that negatively influence girls' participation and consequently their performance in the subject and their future career choices and opportunities(Halpern, D., Aronson, J., Reimer, N., Simpkins, S., Star, J., \& Wentzel, K. ,2007)Mathematics has been stereotyped as a male 
domain it is important to examine how context specificity how the lack of female mathematics role models affects the performance of girls in the South West Region of Cameroon and what could be done to use role models to improve performance.

\section{Background}

Gender differences in mathematics performance is a concern in Cameroon's educational system as girls continue to record low performances in secondary school mathematics tests and examinations as compared to boys. The Cameroon General Certificate of Education (GCE) results in Mathematics reveals that the boys perform better than the girls. According to the records in all the schools studied like Bilingual Grammar School Molyko (BGS) Buea, Cameroon College of Arts and Science (CCAS) Kumba, Government Bilingual High School (GBHS) Tombel, Government Bilingual High School (GBHS) Ekondotiti, Government Bilingual High School (GBHS) Mamfe and Government Bilingual High School (GBHS) Alou within the last five years, more boys than girls passed the GCE mathematics examination. In some of the years, like in 2007 and 2008, the difference is alarming because, apart from the difference in failure rate, the detailed quality (grades) of the results shows that the boys did better. The same kind of result is reflected in the assessment tests and examination scores in all the schools (Fombin, 2002).

Considering the importance of mathematics much worry about this gap amongst scholars, educational authorities and other stakeholders related: to schooling. The importance of teaching mathematics can hardly be over-emphasised. Mathematics is introduced to pupils as early as nursery school and it is compulsory for every student in secondary school. Although it is compulsory, students perform poorly in continuous assessment and end of term examinations.

According to Fombin (2002), the importance of mathematics is articulated to the fact that it is a compulsory subject on the school curriculum in Cameroon which should enable students to develop powerful communication skills leading to precision. Specifically, mathematics equips students with uniquely powerful ways to describe, analyse and change the world. It can stimulate moments of pleasure and wonder for all students when they solve a problem for the first time, discover a more elegant solution, or notice hidden connections. Students who are functional in mathematics and receive all necessary support are able to think independently in applied and abstract ways, and can reason, solve problems and assess risk.

"Mathematical thinking" is important for all members of a modern society as a habit of mind for its use in the workplace, business and finance; and for personal decision-making. Mathematics is fundamental to national prosperity as it is essential in public decision-making and for participation in the knowledge of economy. It is a creative discipline. The language of mathematics is international and its importance is universally recognised over time as a means of solving problems. Mathematics is one of the major subjects in the sciences in which its performance directly and indirectly affects performance in the other science subjects since it provides tools for understanding science engineering, technology, economics and others. It is also important as an entrance requirement to read the science subjects in high school and science disciplines in higher secondary schools and the university programs in Cameroon and other nations of the world.

Despite the importance of this subject, In most of the secondary schools in the South West Region of Cameroon, more boys than girls are actually interested and doing well in mathematics both at the secondary and the university level. there is low participation of girls and women in STEM fields can be observed at all levels of education, with a tendency for female participation to decrease as the level of education rises. This is mirrored in the labor market where their participation further decreases throughout their career path, and women are largely absent in higher level managerial and decisionmaking positions.(Cassy, B. ,2004).

In Cameroon secondary schools, what is taught by the mathematics teacher in class is usually not taken seriously by some students, especially the girls. A number of environmental factors contribute to the gender difference in performance in mathematics. One of these which is the focus of this paper is the absence of female mathematics role models in the schools and the society as a whole. In schools especially for this case under study there are very few female mathematics teachers in secondary schools in the South West Region of Cameroon just like in other regions in Cameroon.

The Poor Performance of Girls in mathematics have linked to some factors related to girls attitude towards maths, teachers pedagogy, parental and other socioeconomic factors( )Study investigates the 
association of lack of female role model in mathematics as one of the plausible explanation of the differences it identifies, and observes in the performance of girls in mathematics, in selected Public Schools in the South West Region of Cameroon. The major objective of this study is to determine if the lack of female role models in mathematics influence the performance of girls in mathematics with a major research question: Does lack of female role models in mathematics influence the performance of girls in mathematics? The findings will influence the female students' perception of mathematics and more girls will be encouraged to take up mathematics and as a result get into some prestigious male dominated professions like engineering, medicine, astrology, accounting and others. It is also hoped that exposure to the hardworking role model and the female role model will reduce stereotype threat among girls.

\section{Lack of Female Role Models in Mathematics and the Performance of Girls in Mathematics}

Role modelling is one of the most pervasive and one of the most powerful means of transmitting values, attitudes, and patterns of thought and behaviour (Bandura, 1986; Rosenthal \& Zimmerman, 1978). Role modelling is not simply a process of response mimicry as commonly believed. Modelled activities convey the rules and structures embodied in the exemplars for generative behaviour. This higher level of learning is achieved through abstract modelling. Rule-governed action patterns differ in specific content and other details but they embody the same underlying rule. Once observers extract the rules and structure underlying the modelled activities, they can generate new patterns of behaviour that conform to the structural properties but go beyond what they have seen or heard. Others are related to the salience, attractiveness, and functional value of the modelled activities themselves.

Models exemplify activities considered appropriate for the two sexes. Children can learn gender stereotypes from observing the differential performances of male and female models. Given comparable access, both sexes learn male and female stereotypes from observing models (Bandura \& Bussey, 1984) as also indicated by FAWE (2005)Positive female role models in the academic fields, especially in mathematics and science subject careers, in many communities, are in short supply and this lack of female role models in mathematics influences the performance of girls negatively. (Ceci, S.J., Williams, W.M., \& Barnett, S.M. ,2009).

Female role models in villages mainly do simple jobs, e.g., cooking and serving food, selling in the market, and in cities are mainly hostesses, secretaries, etc. This has a great influence on the young girls in the community who believe that these women with no scientific or formal education earn money and are well off. They therefore do not see the need or importance of studying mathematics, considering it as a waste of time, especially as it is time consuming.

The short supply of models in mathematics and the other sciences is an issue for the girls. For example, a student who identifies with and admires a mathematics teacher or any profession of the science disciplines may work hard, partly to please the teacher, and towards becoming like the teacher and other role models in future.

A number of studies on the positive impact of female mathematics role models on girls mathematics performance has been recorded. One of them is that of Lawner (2010) on impact of Role Model Gender and Communalityal on College Women's Math Performance and interest in STEM .Her research show role models are relevant, and their success must be perceived as attainable in order for them to be motivational (Lockwood \& Kunda, 1997). The stereotype inoculation model (Dasgupta, 2011) describes how both expert and peer role models can protect in group members' self-concept from belonging threats in domains in which there are negative stereotypes about the group. Role model will reduce stereotype for girls according to her. Essentially, the presence of in group members in an academic or professional context in mathematics can improve sense of belonging, self-efficacy, attitudes, and identification, and can change the perception of a domain in which the in group is negatively stereotyped from that of a threat to that of a challenge. Her findings indicated female role models in mathematics brings positive changes that can in turn increase effort, performance, and active participation, and influence individuals' career decisions. The stereotype inoculation model also suggests that similarity and identification with role models are important moderators of these effects (Dasgupta, 2011). In addition, role model gender has been found to be important for inspiring females, but not males (Lockwood, 2006) as in Lawner (2010)

Following Lawner (2010), number of studies that have examined the effects of female role models for girls 
and women in math and other STEM domains (Cheryan, Drury, \& Vichayapai, 2013; Cheryan, Siy, Vichayapai, Drury, \& Kim, 2011; Marx \& Roman, 2002; Stout, Dasgupta, Hunsinger, \& McManus, 2011). One study examined the impact of the gender of a math role model on women and men's math performance and performance state self-esteem, and found that women and men had equivalent math performance and self-esteem with the female role model, but men performed better and had higher selfesteem with a male role model (Marx \& Roman, 2002). Two follow-up studies used only female role models, but manipulated perceptions of competence, and tested the effects on math performance, performance state self-esteem, and math self-efficacy. Women performed better with a competent female role model, whereas men performed worse with a competent female role model. One of the studies found that the improvement in women's performance was due to increased accuracy, while the other found that it was due to both higher accuracy and attempting more problems. Math self-efficacy was higher for female participants in the competent female role model condition, compared to the non competent female role model condition. Female mathematics role models can encourage girls participation and performance because, because Lawner 2010.op.cit studies shows the effect of female role model competency on women's state self-esteem varied between the two studies, with one study finding that women had lower performance state self-esteem in the competent female role model condition than in the non-competent female role model condition and the other finding the opposite pattern(Lawner ,2010),

\section{Conceptual and Theoretical Framework}

Much of the literature reviewed and discussed shall be within the following conceptual and theoretical framework below.

Concepts which are largely derived from the experience of some of the people of this study have been divulged to explain the characteristics behind the performance of girls in Mathematics. Concepts like, Role Model, Gender, Performance has been examined in this study.

\section{Role Model}

A Role Model is person who serves as an example of the values, attitudes, and behaviours associated with a role. For example, mothers are role model for their daughters. Role models can also be persons who distinguish themselves in such a way that others admire and want to emulate them. For example, a woman who becomes a successful mathematician and engineer can be described as a role model for other women(http://www.businessdictionary.com/definition /role-model.html) An individual who is looked up to and revered by someone else. A role model is someone who other individuals aspire to be like, either in the present or in the future. A role model may be someone who one know and interact with on a regular basis, or may be someone who an individual never met, such as a celebrity. Common role models include well-known actors, public figures such as scientist, police men or political officials, teachers or other educators, and parents or other family members. A female mathematics role model according to this study is those who have been able to pave a way in mathematics. These examples of women within maths discipline who are at different levels of their studies and careers sharing their views on working in Mathematics which can often be seen as male dominated environments. (Lawner 2010)

\section{The Concept "Gender"}

Gender refers to the socially given attributes, roles, activities, responsibilities and needs connected to being men (masculine) and women (feminine) in a given society at a given time and as a member for a specific community within that society. In the last decade, the term "gender" has essentially replaced "sex" or "sex roles" in the discussion of girls and boys in education and other fields of social science. An obvious reason is the unwanted sexual connotation of "sex." that only directly refers to the biological nature of the classification of people and the phrase "sex roles" for some time referred to the social and acquired nature of the observed differences between girls and boys. Gender is widely recognized to be an important empirical variable in understanding many aspects of behaviour. In psychology gender is often used empirically, without much consciousness of its social or conceptual significance, and most often, gender is used to think about ways in which boys and girls or men and women differ, and becomes a framework of interpretation of what is normal or deviant for men and women / boys and girls. According to this "sex differences approach," psychologists consider how and why average differences in personality, behaviour, ability, or performance between the sexes might arise (Block 1984, Buss 1995, Eagly 1994, Levy \& Heller 1992, Maccoby \& Jacklin 1974, and Maccoby 1998). In the context of girls, boys, and science, the term "gender" is now frequently used because it has two obvious advantages. It does not have unwanted sexual 
connotations, and it refers to the social nature of the issue. The distinction between sex and gender also indicates that femininity or masculinity are not biologically determined, but are socially constructed or negotiated, and that they may change over time and may be different from one culture to another.

But the usage of the terms 'sex' and 'gender' is by no means consistent in literature because it is used even in the strict biological sense, as when asking for gender (girl or boy) in a questionnaire. Some argument in favour of using the term gender is made to draw attention to the fact that notions of femininity and masculinity are socially negotiated and not biologically determined. Biological explanations have been used and misused historically to legitimize discrimination based on class, race and sex.

In this study, 'gender' is used as a powerful conceptual tool in at least three ways: (a) in sorting individuals into male and female and exploring the ways in which differences in behaviour, performance, and characteristics are associated with that individual difference; (b) in understanding how gender might relate to individual differences among boys/men and among girls/women; and (c) in understanding how gender structures social institutions such as schools.

In Cameroon and some other African nations, there is a cultural stereotype that Mathematics is for boys and that boys identify themselves with Mathematics more than the girls. Findings suggest that most of these concepts precede ages at which there are cultural differences in mathematics achievements, where the girls rate their own ability lower than boys (Fredericks and Eccles, 2002). Most girls underestimate their own academic ability and believe boys to be relatively superior and more intelligent in handling difficult subjects like Mathematics (Mondoh, 2001). One of the consequences of this gender difference is that teachers, despite their good intentions, might use different standards for boys and girls. Gender issues are points of discussion or controversy pertaining to aspects of the male or female sex, especially in relation to societal or cultural conceptions of masculine and feminine roles or traits.

\section{Concept of "Performance"}

These are scores obtained after assessing students on an achievement task. It is the actual output of a learner after a series of formative and /or summative evaluations, and the direct result of teacher attitude. It is measured in relation to the objectives set ahead by the teacher. If it is good, then the set objectives have been reached, but if it is poor, then they have not been reached. According to Lavin (2010), academic performance refers to some methods of expressing a pupil's scholastic standard.

In educational institutions, success is measured by academic performance, or how well a student meets standards set by local government and the institution itself. As career competition grows ever fiercer in the working world, the importance of students doing well in school has caught the attention of parents, legislators and government education departments alike. The tracking of academic performance fulfils a number of purposes. Areas of achievement and failure in a student's academic career need to be evaluated in order to foster improvement and make full use of the teaching and learning process (Noddings, 1990).

In the past, academic performance was often measured more by earned marks than today. Teachers' observations made up the bulk of the assessment, and today's summation or numerical method of determining how well a student is performing is a fairly recent invention. Different teachers valued different aspects of learning more highly than others, but some standardization has been made in order to make the system fairer in most societies (Santrock, 2001).

Performance in school is evaluated in a number of ways. For regular grading, students demonstrate their knowledge by taking written and oral tests, performing presentations, turning in homework and participating in class activities and discussions. Teachers evaluate in the form of letter or number grades and side notes, to describe how well a student has done. At the state level, students are evaluated by their performance in standardized tests geared toward specific ages and based on a set of achievements students in each age group are expected to meet (Tambo, 2002). This researcher has used teachers' test and exam to display the students' performance. Fennema (1983) and (1986) USA, Australian and British Studies of Girls into Mathematics reveals an inconsistency of findings, with males performing better in some studies and females in others.

\section{The term "Mathematics"}

The nature of mathematics have contributory influence linked role modelling in mathematics. Mathematics in a strict sense is the abstract science which investigates deductively and inductively the conclusions implicit in the elementary conceptions of spatial and numerical relation. It has also been defined as the science of numbers and spaces, and has been 
interpreted and explained in various ways. It is the numerical part of man's life and knowledge. In this context, it is defined as the science of measurement, quantity and magnitude. Its Hindi or Punjabi name is 'Ganita' which means the science of calculation. It is a systematized, organized and exact branch of science.

Mathematics is the science of patterns and relationships. As a theoretical discipline, it explores the possible relationships among abstractions without concern for whether those abstractions have counterparts in the real world. The abstractions can be anything from strings of numbers to geometric figures to sets of equations. As mathematics has progressed, more and more relationships have been found between parts of it that have been developed separately; for example, between the symbolic representations of algebra and the spatial representations of geometry. These cross-connections enable insights to be developed into the various parts; together, they strengthen belief in the correctness and underlying unity of the whole structure.

Mathematics is also an applied science. Many mathematicians focus their attention on solving problems that originate in the world of experience. In contrast to theoretical mathematicians, applied mathematicians, in the examples given above, might study the interval pattern of prime numbers to develop a new system for coding numerical information, rather than as an abstract problem. Or they might tackle the area/volume problem as a step in producing a model for the study of crystal behaviour.

Mathematical thinking often begins with the process of abstraction; that is, noticing a similarity between two or more objects or events. Cockcroft (1982) stated that mathematics is difficult because it deals with abstract relationships, but some parts are so easy that one can answer without understanding the underlying concepts. The hierarchical nature of the subject leads to the fact that the treatment of the different topics can be a problem if concepts which have gone before are not fully understood, or are omitted.

Aspects that they have in common, whether concrete or hypothetical, can be represented by symbols such as numbers, letters, other marks, diagrams, geometrical constructions, or even words. Whole numbers are abstractions that represent the size of sets of things and events or the order of things within a set. The circle as a concept is an abstraction derived from human faces, flowers, wheels, or spreading ripples; the letter A may be an abstraction for the surface area of objects of any shape, for the acceleration of all moving objects, or for all objects having some specified property; the symbol + is commonly used to represent a process of addition, whether one is adding apples or oranges, hours, or miles per hour. Abstractions can be made not only from concrete objects or processes; they can also be made from other abstractions, such as kinds of numbers (the even numbers, for instance) (Dossey, 1990).

Such abstraction enables mathematicians to concentrate on some features of things and relieves them of the need to keep other features continually in mind. As far as mathematics is concerned, it does not matter whether a triangle represents the surface area of a sail or the convergence of two lines of sight on a star; mathematicians can work with either concept in the same way

After abstractions have been made and symbolic representations of them have been selected, those symbols can be combined and recombined in various ways according to precisely defined rules. Sometimes that is done with a fixed goal in mind; at other times it is done in the context of experiment or play to see what happens. Sometimes an appropriate manipulation can be identified easily from the intuitive meaning of the constituent words and symbols; at other times a useful series of manipulations has to be worked out by trial and error. (A. A .A. S., 1990). Also, Cockcroft (1982) as in Burton (1986) expressed the nature of mathematics as widely being:

$>$ A mystique accessible to few;

$>$ Abstract and unrelated to reality;

> Concerned largely with computation;

$>$ Made up of X's and Y's and incomprehensible formula;

A collection of rules and facts to be remembered.

So far as application is concerned, mathematical processes can lead to a kind of model of a thing, from which insights can be gained about the thing itself. Any mathematical relationships arrived at by manipulating abstract statements may or may not convey something truthful about the thing being modelled. For example, if 2 cups of water are added to 3 cups of water and the abstract mathematical operation $2+3=5$ is used to calculate the total, the correct answer is 5 cups of water. Karl (2007) stated that sometimes common sense is enough to enable one to decide whether the results of the mathematics are appropriate, but sometimes a single round of 
mathematical reasoning does not produce satisfactory conclusions.

Generally, the response of students to mathematics is affected by its nature. Some students see it as difficult and complex. The effectiveness of the teaching exercise is also seriously influenced by what mathematics is, and calls for varied teaching skills and methods to facilitate learning for all and especially the female students who most of the time consider it as boring and difficult ( Brophy \& Good, 1986). In secondary school most of the students, especially the girls, are more comfortable with like functions, matrices, Business Mathematics and sets, but are not very comfortable with those like logic, permutation and combination.

\section{Theoretical Perspectives}

The theoretical frameworks that guided this study include the Maslow's Theory of Motivation (1970) and Gero (1997) Motivational Theory and the Social Cognitive Theory (SCT) of gender development and differentiation. These theories highlighting the complexities that girls undergo in the society and classroom which affects their attitude and general participation and performance in secondary school mathematics

In the Maslow's Theory of Motivation (1970) and Gero (1997) Motivational Theory, Maslow (1970) as cited in Smith (1993) developed a hierarchical classification of needs. He said needs are in low and high ranks. He emphasised that it is only when the lower ranking needs are satisfied that the upper or higher ranking needs can be satisfied. For example, a student will only perform well or satisfy his achievement needs when his/her need of belonging has been met.

A student who feels out of place in a mathematics class will give up the task given her or face it poorly, and thus end up with a poor performance. In the case where the female student feels at home or competent in a mathematics class, her achievement need will increase and thus she can perform better. It is only when the female's need of belonging to those who can do well in mathematics is met that the female student can work harder and perform better to meet the achievement needs. According to Gero (1997) as in (Santrock 2002), motivation is the process that arouses, directs and maintains achievement. Hay (1998) states that motivation is the strengthening of learning and Skinner (1953) says organisms tend to repeat actions that are reinforced and that behaviour can be reshaped by reinforcement.
Through positive reinforcement like observation and motivational talks from female mathematics role models, the female mathematics student could feel fit to perform the same task like the male, and the stereotype female incompetence in maths is thereby forgotten. The secondary school mathematics teachers are expected to provide conducive classroom environments, good teaching aids, and safety to enhance performance and where there is a female maths teacher, she would seve as a female model Mathematician.

The Social Cognitive Theory (SCT) of gender development and differentiation explains how the socialization or learning approach is far better to account for gender differences in behaviour and development of gender identity and consequently performance. Here Bandura et al. (1965) and the others emphasize the point that learning occurs in a social context and that much of what is learned is gained through observation. They explain how gendered roles and conduct involve intricate competencies, interests and value orientations. In this theory of gender differentiation they explain the determinants and mechanisms through which genderlinked roles and conduct are acquired.

The first mode is through modelling, the second mode is through enactive experience which relies on discerning the gender-linkage of conduct from the outcomes resulting from one's actions, especially as people have views about what is appropriate conduct for each of the two sexes. The third mode of influence is through direct tuition. It serves as a convenient way of informing people about different styles of conduct and their linkage to gender. This means children gain mobility and competencies to act on the environment. They begin enacting behaviour that is socially linked to gender and experiencing social reactions.

Performance of observationally learned behaviour is regulated by three major types of incentive motivators which are direct, vicarious and self-evaluative. People are more likely to adopt modelled styles of behaviour if they produce valued outcomes than if they have unrewarding or punishing effects (Bandura \& Barab, 1971; Hicks, 1968). The observed cost and benefits accruing to others influence the adoption of modelled patterns vicariously in much the same was as do directly experienced consequences (Bandura, 1965). People are motivated by the success of others who are similar to themselves, but are discouraged from pursuing courses of behaviour that they have seen often result in aversive consequences. The evaluative 
reactions people generate to their own conduct also regulate which observationally learned activities they are most likely to pursue. The phase of gender constancy helps people to start identifying with same sex from whom they learn masculinity or femininity. They express what they find self-satisfying and reject what they personally disapprove.

Apart from promoting differential styles of behaviour, modelling influences can alter incentive motivation (Bandura, 1986). Seeing others achieve valued outcomes by their efforts can instil motivating outcome expectancies in observers that they can secure similar benefits for comparable performances. Modelled performance outcomes thus create incentives and disincentives for action. By the same token, seeing others punished for engaging in certain activities can instil negative outcome expectations that serve as disincentives. These motivational effects rest on observers' judgments that they have the efficacy to produce the modelled performances and that comparable behaviour will bring them similar outcomes.

What gives significance to vicarious emotional influence is that observers can acquire lasting attitudes and emotional and behavioural proclivities toward persons and activities that have been associated with modelled emotional experiences (Bandura, 1992; Berger 1962; Duncker 1938).

The actions of mathematic models in school and in society can also serve as social prompts for previously learned behaviour. The influence of models in activating, channelling, and supporting social behaviour is abundantly documented in both laboratory and field studies (Bandura 1986; Rosenthal, 1984). Thus, the types of models that prevail in a given social milieu starting from the mathematics teachers partly determine which personal qualities, from among many alternatives, the students can choose from.

Mathematics teaching and learning has been an area of much interest to scholars who at different times and in different ways have written on issues related to performance. The general overview is that reviewed literature is that there is a gender difference in the performance in secondary school mathematics which some of the authors suggest is influenced by a number of factors in the school and society that is socio-cultural for which the lack of female mathematics role models in the society is a contributory factor.

\section{METHODOLOGY}

This study is restricted to the form four students with age bracket fifteen to seventeen years and teachers of selected public secondary schools including Bilingual Grammar School (BGS) MolykoBuea, Cameroon College of Arts and Science (CCAS) Kumba, Government High School (GHS) EkondoTiti, Government Bilingual High School (GBHS) Mamfe, Government High school (GHS) Nyassoso and Government High School Alou in the South West Region of Cameroon. It is limited to form four because this is the form where students select subjects to write in the Cameroon G.C.E.

This study will not include the form four Bilingual Class (3eme Bilingue) because almost all of the students in this class, both boys and girls, are a selection of the most intelligent students in all the lower forms of the school, and these are already doing very well in both the arts and the science subjects. The government secondary schools or public schools have been chosen because they are considered as having the ideal conditions the government wants for their secondary schools, a representation of all social, cultural class and groups of students and teachers; trained teachers, the right student teacher ratio and available quality teaching and learning facilities.

The sample consisted of 450 form four mathematics students and 44 mathematics teachers drawn from six secondary schools (one from each Division of the South West Region of Cameroon). These consist of the study is descriptive and combines qualitative and quantitative methods, to investigate the research questions in order to enhance confidence in the ensuing findings. The quantitative approach was concern with the systematic empirical investigation of observable phenomena via statistical, mathematical or computational techniques and the qualitative had to do with the examination, analysis and interpretation of other desktop reviews with the purpose of discovering underlying meanings and patterns of relationships in the study. Both direct and indirect sources of information were used to gather data. The Target population was secondary schools in the South West Region of Cameroon. Through the stratified and the simple random sampling technique, 450 form four students and 44 mathematic teachers were selected as sample. Students and teachers' questionnaire and observation formed the major source of data. The validity and reliability of the instruments were all checked through the pilot study of a small proportion of the target population .Response of the pilot study 
was about $96 \%$ consistent, which was an indication of a high degree of validity and reliability of the instrument.

Both descriptive and inferential statistics and Windows Statistical Package for Social Sciences (SPSS) was used to analyze the data. For descriptive statistics, frequencies, percentages, bar-charts and piecharts, means and standard deviations were used.

\section{FINDINGS}

The Research Question: Does lack of female role models in Mathematics influence the performance of girls in Mathematics?

Show Results on table 1 show an overall mean of 3.281 which lies within the range 2.75 and $4.0(2.75 \leq$ $3.281 \leq 4.0$ ). This makes us answer that lack of female role models in mathematics influences the performance of girls in mathematics.
The sample for teachers was largely dominated by males. Out of 6 teachers, five of them either strongly agree or agree to the statement that there is generally a short supply of female role models in maths and the sciences in most secondary schools in Cameroon. Four of them either strongly agreed or agreed that girls cannot make it in mathematics because most of their maths teachers are male. They indicated that responses to female students' efforts in mathematics by some male teachers are discouraging and cause them to think that a female maths teacher would have been more understanding, and that the existence of more female mathematics teachers in schools will attract more young girls to maths. Three of them either strongly agreed or agreed to the point that most girls prefer females than males to teach mathematics and the science subjects in general.

Table 1: Computation of Means and Standard Deviation on Responses Relating to Lack of Female Mathematics Role Models on Female Students' Performance in Maths

\begin{tabular}{|c|c|c|c|c|c|c|c|c|}
\hline \multirow[t]{2}{*}{$\begin{array}{l}\mathrm{S} / \\
\mathrm{N}\end{array}$} & \multirow[t]{2}{*}{ Statement } & \multirow[t]{2}{*}{ Gender } & \multicolumn{4}{|c|}{$\begin{array}{l}\text { Response Options and } \\
\text { Frequencies }\end{array}$} & \multirow[t]{2}{*}{$\frac{\text { Mean }}{(\bar{X})}$} & \multirow{2}{*}{$\begin{array}{l}\text { Standard } \\
\text { Deviation } \\
\text { (SD) }\end{array}$} \\
\hline & & & SA & A & $\overline{D A}$ & SDA & & \\
\hline \multirow[t]{2}{*}{1} & \multirow{2}{*}{$\begin{array}{l}\text { Girls cannot make it in mathematics because } \\
\text { most of their maths teachers are males }\end{array}$} & Male & 13 & 13 & 5 & 5 & \multirow[t]{2}{*}{3.00} & \multirow[t]{2}{*}{0.489} \\
\hline & & Female & 3 & 1 & 1 & & & \\
\hline \multirow[t]{2}{*}{2} & \multirow{2}{*}{$\begin{array}{l}\text { Most girls prefer females to males to teach } \\
\text { maths and the science subjects in general }\end{array}$} & Male & 19 & 10 & 5 & 1 & \multirow[t]{2}{*}{3.25} & \multirow[t]{2}{*}{0.603} \\
\hline & & Female & 11 & 2 & 1 & 1 & & \\
\hline \multirow[t]{2}{*}{3} & \multirow[b]{2}{*}{$\begin{array}{l}\text { Responses to female students' efforts in } \\
\text { mathematics by some male teachers are } \\
\text { discouraging and cause them to think that a } \\
\text { female maths teacher would be more } \\
\text { understanding }\end{array}$} & Male & 19 & 12 & 3 & 1 & \multirow[t]{2}{*}{3.317} & \multirow[t]{2}{*}{0.319} \\
\hline & & Female & 2 & 2 & 2 & & & \\
\hline \multirow[t]{2}{*}{4} & \multirow{2}{*}{$\begin{array}{l}\text { There is generally a short supply of female role } \\
\text { models in maths and the sciences in most } \\
\text { secondary schools in Cameroon }\end{array}$} & Male & 20 & 12 & 2 & 2 & \multirow[t]{2}{*}{3.415} & \multirow[t]{2}{*}{0.444} \\
\hline & & Female & 3 & 2 & - & - & & \\
\hline \multirow[t]{3}{*}{5} & The existence of many female mathematics & Male & 18 & 16 & 1 & - & \multirow[t]{2}{*}{3.425} & \multirow[t]{2}{*}{0.515} \\
\hline & $\begin{array}{l}\text { teachers in our schools can attract many young } \\
\text { girls to maths }\end{array}$ & Female & 2 & 2 & - & 1 & & \\
\hline & Overall Mean & & & & & & 3.281 & \\
\hline
\end{tabular}

\section{Source: Field Work, 2015}

Results on table1 show why girls prefer to have a female teacher. Prominent amongst the reasons is the belief that if a woman teaches maths, then they too can do it. They indicate the caring nature of women and say they can more easily expose their problems to female teachers. 
International Journal of Trend in Scientific Research and Development (IJTSRD) ISSN: 2456-6470

Table 2: Description of Responses from the Open-Ended Items on why some Girls prefer to have a Female Maths Teacher (Responses by Gender)

\begin{tabular}{|c|c|c|c|c|c|}
\hline $\mathrm{S} / \mathrm{N}$ & Why girls prefer a female maths teacher & Gender & Frequency & $\begin{array}{l}\text { Percentage } \\
(\%)\end{array}$ & \\
\hline \multirow[t]{2}{*}{1} & \multirow{2}{*}{$\begin{array}{c}\text { The belief that if a female maths teacher is } \\
\text { teaching then they too can do it }\end{array}$} & Male & 8 & 19.5 & \multirow[t]{2}{*}{24.4} \\
\hline & & Female & 2 & 4.9 & \\
\hline \multirow[t]{2}{*}{2} & \multirow{2}{*}{$\begin{array}{l}\text { The caring nature of a woman will attract girls, } \\
\text { since they are considered as weaker vessels }\end{array}$} & Male & 7 & 17.1 & \multirow[t]{2}{*}{19.5} \\
\hline & & Female & 1 & 2.4 & \\
\hline \multirow[t]{2}{*}{3} & \multirow{2}{*}{$\begin{array}{l}\text { They can more easily expose their problems to } \\
\text { female teachers }\end{array}$} & Male & 6 & 14.6 & \multirow[t]{2}{*}{19.5} \\
\hline & & Female & 2 & 4.9 & \\
\hline \multirow[t]{2}{*}{4} & \multirow[t]{2}{*}{ They will be more relaxed and more ready to learn } & Male & 4 & 9.8 & \multirow[t]{2}{*}{17.1} \\
\hline & & Female & 3 & 7.3 & \\
\hline \multirow[t]{2}{*}{5} & \multirow{2}{*}{$\begin{array}{l}\text { There will be no sexual harassment of female } \\
\text { students }\end{array}$} & Male & 4 & 9.8 & \multirow[t]{2}{*}{9.8} \\
\hline & & Female & - & - & \\
\hline \multirow[t]{2}{*}{6} & \multirow{2}{*}{ Easy interaction will facilitate learning } & Male & 3 & 7.3 & \multirow[t]{2}{*}{7.3} \\
\hline & & Female & - & 2.4 & \\
\hline 7 & Missing Data & $47 / \mathrm{O}$ & 1 & & 2.4 \\
\hline & Total & & 41 & 100.0 & 100.0 \\
\hline
\end{tabular}

Source: Field Work, 2015

By gender, more girls than female teachers contributed to the seven items on table 2 showing why some girls prefer to have a female maths teacher. This may have been because of their numerical advantage in the sample. However, out of the 6 female teachers in the sample, 3 contributed to the idea that female students may easily expose their problems to female mathematics teachers and 2 contributed to the ideas that the existence of female mathematics teachers shows that girls too can do mathematics, and that the caring nature of a woman (as a teacher) will attract girls to mathematics.

An overall mean of 2 makes us agree that lack of female role models in maths influences the performance of girls in the subject. This is because the mean 3.241 lies within 2.75 and 4.0.

Responses by gender show that more females than males strongly agreed and agreed to all the items on table 44 that indicate that the lack of Female Mathematics Role Models affects girls' participation and performance in mathematics.

Table 3: Computation of Means and Standard Deviations on Responses Relating to Lack of Female Mathematics Role Models (Students' Responses) by Gender

\begin{tabular}{|c|c|c|c|c|c|c|c|c|}
\hline \multirow[t]{2}{*}{$\begin{array}{l}\mathrm{S} / \\
\mathrm{N}\end{array}$} & \multirow[t]{2}{*}{ Statement } & \multirow[t]{2}{*}{ Gender } & \multicolumn{4}{|c|}{$\begin{array}{l}\text { Response Options and } \\
\text { Frequencies }\end{array}$} & \multirow[t]{2}{*}{$\operatorname{Mean}(\bar{X})$} & \multirow[t]{2}{*}{$\begin{array}{c}\text { Standard } \\
\text { Deviation (SD) }\end{array}$} \\
\hline & & & SA & A & $\mathrm{DA}$ & SDA & & \\
\hline \multirow[t]{2}{*}{1} & \multirow{2}{*}{$\begin{array}{l}\text { There are many girls who } \\
\text { cannot make it in maths } \\
\text { because their maths teacher is } \\
\text { a male }\end{array}$} & Male & 100 & 79 & 17 & 15 & \multirow[t]{2}{*}{3.372} & \multirow[t]{2}{*}{0.555} \\
\hline & & Female & 110 & 80 & 16 & 15 & & \\
\hline \multirow[t]{2}{*}{2} & \multirow{2}{*}{$\begin{array}{l}\text { Girls prefer female teachers in } \\
\text { maths and other sciences in } \\
\text { general }\end{array}$} & Male & 105 & 74 & 14 & 18 & \multirow[t]{2}{*}{3.272} & \multirow[t]{2}{*}{0.669} \\
\hline & & Female & 100 & 90 & 14 & 7 & & \\
\hline \multirow[t]{2}{*}{3} & \multirow{2}{*}{$\begin{array}{l}\text { Responses to girls' efforts in } \\
\text { maths by some male teachers } \\
\text { are so discouraging that they } \\
\text { think female maths teachers } \\
\text { would be more understanding }\end{array}$} & Male & 100 & 91 & 10 & 12 & \multirow[t]{2}{*}{3.313} & \multirow[t]{2}{*}{0.418} \\
\hline & & Female & 99 & 100 & 10 & 10 & & \\
\hline
\end{tabular}


International Journal of Trend in Scientific Research and Development (IJTSRD) ISSN: 2456-6470

\begin{tabular}{|c|c|c|c|c|c|c|c|c|}
\hline \multirow[t]{2}{*}{4} & \multirow{2}{*}{$\begin{array}{l}\text { There is generally a shortage } \\
\text { of female role models in maths } \\
\text { in most secondary schools in } \\
\text { Cameroon }\end{array}$} & Male & 89 & 75 & 20 & 5 & \multirow[t]{2}{*}{3.212} & \multirow[t]{2}{*}{0.813} \\
\hline & & Female & 112 & 74 & 30 & 25 & & \\
\hline \multirow[t]{2}{*}{5} & If there exist many female & Male & 75 & 92 & 35 & 9 & \multirow[t]{2}{*}{3.101} & \multirow[t]{2}{*}{0.466} \\
\hline & $\begin{array}{l}\text { models many young girls will } \\
\text { do maths }\end{array}$ & Female & 81 & 95 & 15 & 21 & & \\
\hline & Overall Mean & & & & & & 3.241 & \\
\hline
\end{tabular}

\section{Source: Field Work, 2015}

Table 3 shows the reasons some girls prefer female maths teachers. Prominent amongst these reasons are the fact that female maths teachers are more caring, that the girls will be motivated to do maths when they see that the teacher is a female because female teachers are more systematic in their approach, more attentive to students' problems and the female students can easily share their problems with them.

Responses by gender show that more females than males contributed ideas to items that the female mathematics teacher will be more caring. As such, the girl child will be more motivated to learn when she sees someone of the same sex teaching. More males than females contributed to the ideas that girls may prefer the female mathematics teachers since they can easily share their learning difficulties with them.

\section{Table 4: Reasons why some Girls prefer to have a Female Maths Teacher (Responses by Gender)}

\begin{tabular}{|c|c|c|c|c|c|}
\hline $\mathrm{S} / \mathrm{N}$ & Reasons & Gender & Frequency & $\begin{array}{l}\text { Percentage } \\
(\%)\end{array}$ & $\begin{array}{l}\text { Combined } \\
\text { percentages }\end{array}$ \\
\hline \multirow[t]{2}{*}{1} & She will be more caring & Males & 54 & 12.5 & \multirow[t]{2}{*}{28.7} \\
\hline & & Females & 70 & 16.2 & \\
\hline \multirow[t]{2}{*}{2} & \multirow{2}{*}{$\begin{array}{l}\text { The girl child will be more motivated to learn } \\
\text { when she sees someone of the same sex teaching }\end{array}$} & Males & 30 & 6.9 & \multirow[t]{2}{*}{13.4} \\
\hline & & Females & 33 & 7.5 & \\
\hline \multirow[t]{2}{*}{3} & \multirow{2}{*}{ They are more systematic in their approach } & Males & 20 & 4.6 & \multirow[t]{2}{*}{13.4} \\
\hline & & Females & 38 & 8.8 & \\
\hline \multirow[t]{2}{*}{4} & \multirow{2}{*}{ Female teachers are more attentive } & Males & 25 & 5.8 & \multirow[t]{2}{*}{13.0} \\
\hline & & Females & 31 & 7.2 & \\
\hline \multirow[t]{2}{*}{5} & \multirow{2}{*}{ They can easily share their problems to them $\angle 4$. } & Males & $25 \quad 0=$ & 5.8 & \multirow[t]{2}{*}{9.5} \\
\hline & & Females & 16 & 3.7 & \\
\hline \multirow[t]{2}{*}{6} & \multirow{2}{*}{$\begin{array}{l}\text { They are not distracted because of same sex, so } \\
\text { they learn better }\end{array}$} & Males & 16 & 3.7 & \multirow[t]{2}{*}{7.4} \\
\hline & & Females & 16 & 3.7 & \\
\hline \multirow[t]{2}{*}{7} & Missing Data & & $32>$ & 7.4 & 7.4 \\
\hline & Total & & 432 & 100.0 & 100.0 \\
\hline
\end{tabular}

\section{Source: Field Work 2015}

Responses for item 6 show that there is a shortage of female mathematics role models. This eventually accounts for the poor performance of girls in maths as recorded also on table 4 for research question five on whether the absence of female mathematics role models influences the performance of girls in mathematics.

Table 5: Distribution of Classified Respondents using the Nominal Scale of Measurement on Lack of Female Role Models in Mathematics

\begin{tabular}{|l|l|l|}
\hline Lack of female role models & Frequency & Percentage (\%) \\
\hline Significant & 391 & $\mathbf{8 2 . 7}$ \\
\hline Not significant & 82 & $\mathbf{1 7 . 3}$ \\
\hline Total & 473 & 100.0 \\
\hline
\end{tabular}

Source: Field Work 2012

By using the response format and weighting scale and applying the various codes, $82.7 \%$ of respondents were classified to have said that the lack of female role models in maths is significant. $17.3 \%$ had a contrary view. 


\section{Discussion}

For the influence of female role models in mathematics on the performance of girls, on the question on whether lack of female role models in Mathematics influence the performance of girls in Mathematics, Computation of Means and Standard Deviation on Responses relating to Lack of Female Mathematics Role Models on Female Students' Performance in Maths Results on table1 show an overall mean of 3.281 which lies within the range 2.75 and $4.0(2.75 \leq 3.281 \leq 4.0)$. This shows us that lack of female role models in mathematics influences the performance of girls in mathematics. In all six schools, girls especially complained there are very few role models in mathematics especially as most of their mathematics teachers are males. According to Bandura's (1966) Social Learning theory, humans learn through the observation, imitation and modelling of other people. His theory of social modelling terms as efficiency information, the fact that students could tend to view the Mathematics teacher as role model to emulate. Students could view them as competent enough in the field and would be motivated to take up the challenge, thus performing better in the subject. This is in line also with Nancy's (1999) observation that the absence of senior women scientists, especially in most public areas in Africa, translates that girls have few role models with whom to identify and few female mentors to encourage them (Blanton, H., Christie, C., \& Dye, M., 2002).

To compare with other studies, talking on the importance of female role models in mathematics, Lawner( 2010) showed that A recent review examined several potential causes of women's underrepresentation in STEM fields (Ceci, Williams, $\&$ Barnett, 2009). The review indicated that there is little evidence that there are genetic or biological differences in ability, and, indeed, if representation in math-intensive careers was based solely on math ability, women's representation would double, demonstrating that ability cannot be the primary cause of women's underrepresentation in STEM. The review concluded that four main factors contribute to women's underrepresentation in math-intensive careers. First, more men than women score at the highest end on math or quantitative sections of gatekeeper tests such as SAT and GRE. This gender difference on the GRE-Q is particularly problematic because it leads to men being admitted to graduate programs in math-intensive fields at greater rates than women. Second, women with high math competence are disproportionately likely to also have high verbal competence, compared with men, which allows women with high math competence more career options in non-STEM careers. Third, math-proficient women are more likely than math-proficient men to prefer careers in non-math-intensive fields, and for the women who do enter math-intensive fields, they are more likely than men to leave those careers as they advance. Finally, in some math-intensive fields, women are penalized in promotion rates for having children (Ceci et al., 2009). The exposure to female mathematics role model will produce positive effects on girls participation and performance in mathematics. (Lawner, 2010)

It was also indicated in the field report that the existence of many female mathematics teachers in our schools can attract more young girls to Mathematics. Wynarczyk (2013) also states that female role models in science and mathematics are largely invisible; that there is negative labelling of women in scientific and technological fields and that lack of female role models is affecting the current labour market. A lack of exposure and of genuine representation jeopardizes the opportunity to inspire the next generation through shining examples of women in science and technology. Exposure to positive role models during the critical junctures, like the earlier years of education, has a positive influence on self-efficacy and, hence, on inspiring future career choices for girls. Female role models are incredibly important as they allow individuals to showcase their achievements. They can also encourage more girls to get involved, especially in areas such as mathematics, science and technology which have traditionally been associated with men.

\section{Conclusion}

Studies on role models and mathematics from the West, Africa, Cameroon and other developing countries reveals a decline in the gap between boys' and girls' achievements in mathematics. The increase of mathematics role model cans contribute to girl's performance in mathematics. Increase of women in the mathematics profession will reduce the cycle of stereotypes and upholding of these stereotypes that females are less mathematically capable than males. More females will then start taking advanced math courses in high school or college, believing they too like the models can make it. 
What is important about this paper is that females perform as well as males in mathematics, especially where they are motivated or given an enabling environment. capable of performing well in mathematics. This will lead to more parent and academic support, and more enabling environments that further enhance female ability to perform well. It is important at this point to say that there is need to continue to encourage girls, especially high ability girls, to continue in mathematics so as to keep open their option to pursue science careers as stated by Betz (1997) and Betz, D.E., \& Sekaquaptewa, D. (2012).

\section{Recommendations}

Because the findings from this study have implications gender difference in terms of professional development, a lot needs to be done to bridge the observed gender gap in mathematics role Models in Cameroon. The concerted effort of teachers, parents, students, the Ministry of Secondary Education, the Cameroon G.C.E Board, Provincial Delegates of Education and other educational institutions is needed. The Government should take a commitment to change the socialisation process within schools which cause girls to be aware that they are unequal to boys. There is need for good gender relations within the school (Endeley, 2004). In policy Support programmes and initiatives for female STEM professionals would help to address some of the factors which can cause them to discontinue their careers, including family responsibilities. This will equip them with the most up-to-date knowledge and skills in fields which experience fast-paced change and innovation.

Teachers should expose girls to female role models who have succeeded in math and science because exposure to positive role models has been found to have a positive impact on young women's math performance and can help dispel negative stereotypes. To help students find positive role models, the authors suggest that teachers assign biographical readings about women scientists, mathematicians, and engineers. The names of the female mathematicians like Hypatia, Marie Agnesi, Sophie Germain, Evelyn Boyd Granville, Sonya Kovalevskaya, and Mary Somerville, among others, can be made known to the students. Teachers can make these women come alive by celebrating their birthdays, hanging their portraits on bulletin board displays, and encouraging females to perform as them. Femalemathematics students need female role models in mathematics.(Lockwood, P.
,2006).Teachers can also draw students' attention to current achievements of women in math and science and possibly invite women or older female students to speak to students about their experiences in these fields. When children are enrolled in school, parents should encourage both boys and girls to take mathematics seriously because mathematics is not meant for a particular gender.

\section{REFERENCES}

1. American Association of University Women. (2000). Tech-savvy: Educating girls in the new computer age. Retrieved August 22, 2002, from http://www.aauw.org/2000/techsavvybd.html

2. Bailey, S. M. \& Campbell, P. B. (1999). The gender wars in education. Retrieved July 19, 2001 from http://www.campbellkibler.com/Gender_Wars.htm

3. Betz, D.E., \&Sekaquaptewa, D. (2012). My fair physicist? Feminine math and science role models demotivate young girls. Social Psychological and Personality Science, 3, 738746.

4. Blanton, H., Christie, C., \& Dye, M. (2002). Social identity versus reference frame comparisons: The moderating role of stereotype endorsement. Journal of Experimental Social Psychology, 38, 253-267.

5. Bouffard, J.A. (2006). Methodological and Theoretical Implications of Using SubjectGenerated Consequences in Tests of Rational Choice Theory. Justice Quarterly, 19(4), 747771

6. Bruner, J. (1966). Toward a Theory of Instruction. Cambridge, MA: Harvard University Press.

7. Dweck, C. S. (2000). Self-Theories: Their Role in Motivation, Personality, and Development. New York: Psychology Press.

8. Cassy, B. (2004). Pupils' gender and attitude towards mathematics in Mozambique. Paper presented at the 10th International Congress on Mathematical Education. Denmark, Copenhagen.

9. Ceci, S.J., \& Williams, W.M. (2011). Understanding current causes of women's underrepresentation in science. Proceedings of the National Academies of Science, 108, 3157- 
3162.

10. Cheryan, S., Drury, B.J., \&Vichayapai, M. (2013). Enduring influence of stereotypical computer science role models on women's academic aspirations. Psychology of Women Quarterly, 37, 72-79.

11. Cheryan, S., Siy, J.O., Vichayapai, M., Drury, B.J., \& Kim, S. (2011). Do female and male role models who embody STEM stereotypes hinder women's anticipated success in STEM? Social Psychological and Personality Science, 2, 656664.

12. Dasgupta, N. (2011). Ingroup experts and peers as social vaccines who inoculate the selfconcept: The stereotype inoculation model. Psychological Inquiry, 22, 231-246.

13. Diekman, A.B., Brown, E.R., Johnston, A.M., \& Clark, E.K. (2010). Seeking congruity between goals and roles: A new look at why women opt out of science, technology, engineering, and math careers. Psychological Science, 21, 10511057.

14. Diekman, A.B., Clark, E.K., Johnston, A.M., Brown, E.R., \& Steinberg, M. (2011). Malleability in communal goals and beliefs influences attraction to STEM careers: Evidence for a role congruity perspective. Journal of Personality and Social Psychology, 101, 902918.

15. Dweck, C. S. (2007). Is math a gift? Beliefs that put females at risk. In S. J. Ceci\& W.M. Williams (Eds.), Why aren't more women in science? Top researchers debate the

16. Ellison,G. and Swanson, A.(2010). 'The Gender Gap in Secondary School .Cambridge: UniversityPess.

17. Endeley, J. (ed) (2006). Challenge, Activism and Aims for a Gender Balanced Society WGS-UB; MINPROF.

18. Federick k. \&Ecclesiias k (2012) Girls attitude in Mathematics www.loot.co.za/index/html/index 1943.html

19. Fennema, E. (2002). Gender equity for mathematics and science. Retrieved August4, 2004, from http://www.woodrow.org/teachers/math/gender/ 02 fennema.html
20. Forum for African Women Educationalist (FAWE) The ABC of Gender Responsive Education Policies FAWE Nairobi, 2002

21. Frances. B.,Kolma, W.K (2005). Feminist theory. A reader, second edition, McGraw-Hill Companies, INC.

22. Gallagher, A. \& Kaufman, J. (Ed.). (2005). Gender Differences in Mathematics. An Integrative Psychological Approach. Cambridge: University Pess.

23. Halpern, D., Aronson, J., Reimer, N., Simpkins, S., Star, J., \&Wentzel, K. (2007). Encouraging girls in math and science: IES practice guide (NCER 2007-2003). Washington, DC: Institute of Educational Sciences, U.S. Department of Education. Retrieved from http://ies.ed.gov/ncee/wwc/pdf/practice_guides/2 0072003.pdf.

24. Lockwood, P. (2006). "Someone like me can be successful": Do college students need samegender role models? Psychology of Women Quarterly, 30, 36-46.

25. Michelle, M.(C) 1994-2009 Girls' Attitudes, SelfExpectations, and Performance in Math. An Annotated Bibliography2010 by Drexel University. http://mathforum.org.

26. Halpern, D., Aronson, J., Reimer, N., Simpkins, S., Star, J. R., \&Wentzel, K. (2007). Encouraging girls in math and science: IES practice guide (NCER 2007-2003). Washington, DC: National Center for Education Research, Institute of Education Sciences, U.S. Department of Education. Available from http://ies.ed.gov/ncee/wwc/publications/practice guides/

27. Kyriacou, O., (2006). Gender ethnicity and professional membership; the case of the UK accounting profession: University of East London.

28. Maccoby, E.E and Jacklin, C.N.(1973).Sex differences in intellectual functioning in a pluralistic society.

$i$. Preceding of the 1972 International Conference on Testing Problems, Educational

ii. Testing Service Princeton, New Jersy 87.

29. Maccoby ,E. and Jackline C. (1974). The psychology of sex differences, Stanford, cliff, 
Stanford University Press.

30. Martin H. et al. (2006). Girls in the Physics/Computer Classroom: A Teacher Guide. New York. Springer Verlag.

31. Maslow, A (1970) Motivation and Personality. 2nd edition, New York, Harper Press.

32. McLeod, S. A. (2011). Bandura - Social Learning Theory. Retrieved from http://www.simplypsychology.org/bandura.html

33. Mendick, H. (2006). Masculinities in Mathematics. Maidenhead: Open University Press.

34. Mendick, H. (2002). Narratives of gender and mathematics. In Proceedings of the third international conference of Mathematics Education and Society (MES3). Denmark 2002.

35. Marx, D.M., \& Roman, J.S. (2002). Female role models: Protecting women's math test performance. Personality and Social Psychology Bulletin, 28, 1183-1193.

36. National Science Foundation. (2013). Women, minorities, and persons with disabilities in science and engineering: 2013. Arlington, VA: Author. Retrieved $\quad$ from http://www.nsf.gov/statistics/wmpd/2013/.

37. Nekang FN (2007) Mathematics Education in Cameroon: Issues, Expectations and the way forward.

i. Journal of Research in Education 4(2), 53-56

38. Noddings, N. 1990. Constructivism in mathematics education. In R.B Davis E.A macher and N. Noddings (Eds) construction views on the teaching and learning of mathematics.

39. Ofsted (2006). Evaluating mathematics provision for 14-19 year-olds. London: Ofsted. Omen Educationalist (FAWE), Nairobi.

40. Papanastasiouc (2002) .Gender difference in mathematics achievement among 8th grade student sin Malaysia; journal of science and mathematics education, Volume 6. Pp 559-571.

41. Pietch, J., Walker, R., and E. Chapman. (2003). The relationship among self-concept, selfefficacy, and performance in mathematics during secondary school. Journal of Educational Psychology 95(3): 589-603.
42. Ritzer, G.(2007). Contemporary Sociological Theory and its classical roots. The Basics, Second Edition, McGraw-Hill Companies.

43. Spelke, E. S. (2005). Sex differences in intrinsic aptitude for mathematics and science? A critical review. American Psychologist, 60(9), 950-958.

44. Stout, J.G., Dasgupta, N., Hunsinger, M., \& McManus, M.A. (2011). STEMing the tide: Using ingroup experts to inoculate women's self-concept in science, technology, engineering, and mathematics (STEM). Journal of Personality and Social Psychology, 100, 255270.

45. Tchombe, T. M. S. (2004) Psychological Parameters in Teaching: Presses Universitairesd'Afriques Yaounde.

46. Torto, R (2002). A Status of girls, participation and performance in SMT subject in secondary schools. FEMSA Discrimination Report $\mathrm{N}^{0} 10$ Forum for African Women Educationalist (FAWE), Nairobi.

47. Williamson, A. (2004). Take-up of Mathematics beyond GCSE. Unpublished study for the City 